sion of the application of science to industry.-P. Fatou : Suites of analytical functions.-Cr. Julia : Surfaces defined by a kinematic property.-J. Guillaume: Observations of the sun made at the Lyons Observatory during the second quarter of Igrs. Summary of observations made on seventy-seven days of the spots, their distribution in latitude, and the distribution of the faculæ in latitude.--E. Belot: The rôle of the satellite material in the structure of the surfaces of the earth, the planets, and the sun.-A. Portevin: Comparison between the internal clastic equilibrium of alloys after tempering and after hardening by drawing in the cold. A comparison of the internal strains developed in a $60 / 40$ brass by tempering at $760^{\circ} \mathrm{C}$. in water and by wire-drawing.-MM. R, Dubrisay, Tripier, and Toquet : The miscibility of phenol and alkaline liquids. The relation between the temperature of complete miscibility of phenol and alkaline solutions of varying concentrations has been studied and the results given graphically-L. F. Navarro: The constitution of the Island of Gomera (Canary Islands).-A. Vacher: The morphogeny of the roadstead of Brest.-P. Pruvost : The fossil fishes of the Coal Measures of the North of France.-M. Molliard : The influence of certain conditions on the comparative consumption of glucose and levulose by Sterigmatocystis nigra starting from saccharose.-A. Paillot: Some new parasitic coccobacilli of the cockchafer.

\section{BOOKS RECEIVED.}

Man's Redemption of Man: A Lay Sermon. By William Osler. Reprint. Pp. 63. (London: Constable and Co., Ltd.) 7 d. net.

Chemistry Notes and Papers for School Use. (Notes and Question Papers to Supplement the Pupil's own Laboratory Notes.) Part i.: Introductory and First-year Work. In nine sections-A to I. Pp. II4. Part ii.: Second-year Work. In seven sections-A to G. Pp. ror. Part iii. : Third-year Work. In eight sections $-A$ to $H$. Pp. r23. By G. N. Pingriff. (London: "Geographia," Ltd.) 2s. 3d. net each part.

I School Chemistry Method: Being the Teacher's Supplement to Chemistry Notes and Papers. Parts i., ii., and iii. By G. N. Pingriff. Pp. $x i i+80$. (London: "Geographia," Lid.) is. gd. net.

Afforestation. By John Boyd. Pp. 39. (London : W. and R. Chambers, Ltd.) is. net.

La Face de la Terre (Das Antlitz der Firde). By Prof. E. Suess. Traduit avec l'autorisation de l'auteur et annoté sous la ditection de E. de Margeric. Tome iii., 4e Partic. Tables Générales de l'ouvrage. Tomes i.-iii. Pp. 258 . (Paris: A. Colin.) 25 francs.

From Darwinism to Kaiserism. By Dr. R. Munro. Pp. xviii + I75. (Glasgow: J. Maclehose and Sons.) $4 s$. net.

Intravenous Injection in Wound Shock. By Prof. W. M. Bayliss. Pp. xi+rz2. (London: Iongmans and Co.) 9 s. net.

Can We Compete? By G. E. Mappin. Pp. x+ 449 . (London: Skeffington and Son, Ltd.) 4s. 6d. net.

\section{DIARY OF SOCIETIES.}

\section{THURSDAY, JANUARY}

Institution of Electrical. Engineers, at 6.-M. B. Field: 'The Navigational (Magnetic) Compass as an Instrument of Prerision.

Opticai Societr, at 7.-T.t.-Col. A. C. Williams: The Design and Inspection of Certain Optical Munitions of War.

FRIDAY, January ro.
Royal Astronomical Society, at $5-$ Rev. A. L. Cortie: The Spectrum of Nova Aquilæ, 19 18, June 15.-J. K. Fotheringham: The New Star of Hipparchus and the Dates of Birth and Accession of Mithridates.-Rev. NO. 2567 , VOL. IO2] J. G. Hagen : Observations of Nova Aquila, xgr8.-A. Stanley Williams :
The Variable Star B.D. $+39^{\circ}, 3476$. MONDAY, JANUARY 13

ROYAL InStitution, at 3.-Prof. Spenser Wilkinson: Lessons of the War.

Roval Geographical Society, at 8.-James Berry : Transylvania and it Relation to Ancient Dacia and Modern Rumania.
Relat TUESDAY, JANUARY Y4

Institution of Civil. Engineers, at 5.30.-A. G. Cooper: Slips and Subsidences on the Ceylon Government Railways. - F. W. Scott: Pieter. maritzburg.Riet Spruit Deviation.

Mineralogica:. Suciety, at 5.30.-A. Hutchinson : Stereoscopic Lanternslides of Crystal Pictures.-L. J. Spencer: Mineralogical Characters of Turite ( $=$ Turgite) and some other Iron-ores from Nova Scotia WEDNESDAY, JANUAKY I5.

Roval. SOcIETy of ARTS, at 4.30.-A. F. Kendrick : English Carpets. Entomological Society, at 8.-Annual Meeting.

Royal Microscopical Society, at 8.-J. E. Barnard: Presidential Address : The Limitations of Microscopy. THURSDAY, JANUARY I6.

Royal Institution, at 3.-Prof. J. N. Collie: Chemical Studies of Oriental Porcelain.

ROYAL SOCIETY OF ARTs, at 4.30.-H. Kelway-Bamber, M.V.O. : Coal and Mineral Traffic on the Indian Railways.

LinNEAN Society, at 5.-Capt. A. W. Hill : The Care of Soldiers' Graves. -N. E. Brown: Old and New Species of Mesembryanthemum, with Critical Remarks.-Dr. J. R. Leeson: Exhibition of Mycetozoa from Epping Forest.

Chemical Societry, at 8.

FRIDAY, JANUARY I7.

Royal Institution, at 5.30.--Sir J. Dewar: Liquid Air and the War.

CONTENTS.

PAGE

Optical Research and Design. By Dr. S. Brodetsky 36 Petrol and Petroleum . . . . . . . . . . . $36 \mathrm{I}$ Wool Industries . . . . . . . . . . . . . . . . . . . 362 Our Bookshelf Letters to the Editor:-

Some Temperature Anomalies. (Wilh Map.)-Hy.

$\begin{array}{ll}\text { Harries } & \\ \text { The Perception of Sound.-Prof. D. Fraser Harris } & 364\end{array}$

A Mistaken Butterfly.-Dr. John Aitken, F.R.S. . 366

The Future of British Mineral Resources. By Prof, H. Louis . * * * . . . . * *

Supersaturation and Turbine Theory. By Prof. H. L. Callendar, F.R.S. ${ }^{\circ}$. By Prof, R. T. The Epidemiology of Phthisis. By Prof. R. T.

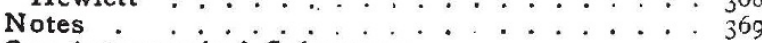

Our Astronomical Column :-

Schorr's Comet........... 373

Opposition of Juno . . . . . . . . . . . . . 373

Twelve New Spectroscopic Binaries. . . . . . . 373

The Minor Planet 692 Hippodamia. . . . . . . 373

Observations of Eros . . . . . . . . . . . . 373

Paris Academy of Sciences: Prizes Proposed for I 920

The Association of Public School Science Masters 374 Mr. Fisher and the Board of Education. Observations on the Results of Our System of Education. By Col. Sir Ronald Ross, K.C.B., K.C.M.G., F. K. S. . * . . . . 376 University and Educational Intelligence .. .378

Societies and Academies . . . . . . . . . . . . 379

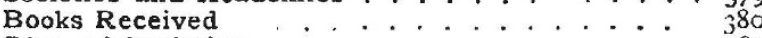
Diary of Societies .............. . . . 380

Editorial and Publishing Offices:

MACMILLAN AND CO., LTD.

ST. MARTIN'S STREET, LONDON, W.C.2.

Advertisements and business letters to be addressed to the Publishers.

Editorial Communications to the Editor.

Telegraphic Address: Puusis, Lovdon.

Telephone Number: GERRARD 8830. 